\title{
ANALISIS PREDIKSI KEBANGKRUTAN PERUSAHAAN DENGAN MODEL ZMIJEWSKI PADA PT BENTOEL INTERNASIONAL INVESTAMA Tbk
}

\author{
Hendy Satria \\ STIE Pembangunan Tanjungpinang \\ Hendysatria@stie-pembangunan.ac.id \\ Ari widyawati \\ STIE Pembangunan Tanjungpinang \\ ariwati211@gmail.com
}

\begin{abstract}
Abstrak : Penelitian bertujuan untuk mengetahui keadaan PT Bentoel International Investama Tbk menggunakan analisis prediksi kebangkrutan metode Zmijewski (X-Score). Metode yang digunakan yaitu deskriptif kuantitatif. Data digunakan adalah laporan keuangan PT Bentoel Internasional Investama Tbk berupa laporan neraca dan laporan laba/rugi tahun 2013-2018. Hasil penelitian menunjukkan bahwa pada tahun 2013 sampai dengan 2015 PT Bentoel berpotensi bangkrut, hal ini terjadi karena pada tahun 2013 sampai dengan 2015 jumlah kewajiban yang dimiliki oleh PT Bentoel lebih tinggi daripada jumlah aset yang dimiliki oleh perusahaan dan ditambah dengan kerugian yang diderita menyebabkan PT Bentoel berada dalam posisi berpotensi bangkrut. Sedangkan ditahun 2016 sampai dengan 2018 PT Bentoel berada dalam posisi sehat. Hal ini terjadi karena perlahan-lahan PT Bentoel mampu menurunkan jumlah kewajibannya sehingga nilai aset PT Bentoel lebih tinggi daripada kewajibannya, meskipun dalam rentang tahun 2016 sampai dengan 2018 PT Bentoel masih mengalami kerugian, namun kerugian yang diderita pada 2017 dan 2018 tidak sebesar pada tahun sebelumnya yang mencapai triliunan rupiah.
\end{abstract}

Kata Kunci : Prediksi Kebangkrutan, Metode Zmijewski

Abstract. The study aims to determine the state of PT Bentoel International Investama Tbk using the Zmijewski method of bankruptcy prediction analysis (X-Score). The method used is descriptive quantitative. The data used is the financial statements of PT Bentoel Int ernasional Investama Tbk in the form of a balance sheet and income statement for 2013-2018. The results showed that in 2013 to 2015 PT Bentoel had the potential to go bankrupt, this happened because in 2013 to 2015 the amount of liabilities owned by PT Bentoel was higher than the total assets owned by the company and added to the loss suffered caused PT Bentoel is in a potentially bankrupt position. Whereas in 2016 to 2018, PT Bentoel was slowly able to reduce its total liabilities so that the value of PT Bentoel's assets was higher than its liabilities, although in the range of 2016 to 2018 PT Bentoel was still experiencing losses, but the losses suffered in 2017 and 2018 were not as large in the previous year which reached trillions of rupiah.

Keywords: Prediction Bankruptcy, Zmijewski Method

\section{PENDAHULUAN}

Sektor industri rokok merupakan bisnis

yang sangat menjanjikan di Indonesia dan menempatkan pemiliknya sebagai daftar orang terkaya. Industri rokok juga merupakan salah satu sumber pemasukan kas negara terbesar 
melalui tarif cukai yang mencapai triliunan rupiah. Data dari Badan Pusat Statistik menampilkan kenaikan mulai tahun 2007 dengan total pemasukan dari tarif cukai sebesar Rp44,68 triliun dan terus menerus mengalami peningkatan hingga Rp145,53

triliun ditahun 2016. Meningkatnya pemasukan dari tarif cukai industri rokok terhadap pendapatan kas negara membuktikan besarnya peran industri rokok bagi perekonomian di indonesia. PT Bentoel Internasional Investama Tbk atau Bentoel Group adalah perusahaan yang memproduksi dan menjual berbagai jenis produk olahan berbahan tembakau diantaranya rokok kretek tangan, rokok kretek mesin dan rokok putih, seperti Dunhill Filter, Dunhill Mild, Club Mild dan Lucky Strike Mild serta telah menyerap lebih dari 6.000 orang karyawan. PT Bentoel didirikan oleh Ong Hok Liong pada tahun 1930-an yang mana pada akhir tahun 1960-an, PT Bentoel adalah perusahaan pertama yang memproduksi dan memasarkan rokok kretek filter buatan mesin dan membungkus kotak rokoknya dengan plastik di indonesia. Inovasi yang dikembangkan oleh PT Bentoel ini menjadi standard pada perindustrian olahan rokok tembakau nasional. Pada tahun 1987 perusahaan PT Bentoel mulai menjadi perusahaan go publik yang terdaftar di Bursa Efek Jakarta. Peraturan Menteri Keuangan (Permenkeu) Nomor 78 Tahun 2013 tentang Penetapan Golongan dan Tarif Cukai Hasil
Tembakau pelan-pelan mematikan industri rokok. Rencana Kementerian Keuangan untuk menaikkan tarif cukai rokok sebesar $10 \%$ berpotensi membuat bangkrut puluhan perusahaan industri rokok tembakau di Indonesia, termasuk perusahaan besar seperti PT Bentoel, Djarum, dan Sampoerna. PT Bentoel sendiri mengalami kemunduran signifikan akibat kebijakan tersebut. Penjualan rokok perusahaan tersebut turun sebanyak 2,5\% dari 10 miliar batang menjadi 6 miliar batang dalam setahun terakhir. Kemunduran penjualan tersebut pun langsung menghantam perusahaan terutama dari sisi beban pokok penjualan dan beban operasi. Terjadinya peningkatan pada beban tersebut didorong oleh faktor kenaikan tarif cukai yang menyebabkan harga tembakau dan bahan baku lainnya ikut meningkat, serta depresiasi nilai rupiah yang lebih tinggi. Beban pokok penjualan PT Bentoel pada tahun 2013 tercatat sebesar Rp10,65 triliun. Kemudian di tahun 2015 semakin naik menjadi Rp15,10 triliun, lebih tinggi dari pada tahun sebelumnya pada 2014 senilai Rp12,87 triliun. Pada tahun 2016 beban pokok penjualan PT Bentoel kembali mengalami kenaikan menjadi Rp17,10 triliun bersamaan dengan naiknya beban operasional perusahaan menjadi $\mathrm{Rp} 2,88$ triliun dari tahun sebelumnya yaitu Rp2,57 triliun. Pada tahun 2017 beban pokok penjualan kembali mengalami kenaikan menjadi Rp18,16 triliun dan pada tahun selanjutnya, yaitu 2018 beban 
yang ditanggung perusahaan sudah mencapai

Rp19,26 triliun. Berdasarkan latar belakang diatas penelitian ini bertujuan untuk mengetahui apakah PT Bentoel International Investama Tbk berada dalam posisi aman atau malah berpotensi akan bangkrut apabila dilihat dari data laporan keuangan dengan menggunakan analisis Zmijewski (X-Score).

\section{METODE PENELITIAN}

Penelitian ini menggunakan metode deskriptif kuantitatif yaitu data yang bersifat angka-angka yang berasal dari perhitungan masing-masing atribut untuk menganalisis suatu objek penelitian. Dalam menyelesaikan penelitian ini menggunakan 2 teknik pengumpulan data, yaitu teknik

dokumentasi dan studi kepustakaan. Dokumentasi yang digunakan dalam hal ini berarti mengambil laporan keuangan PT Bentoel International Investama, Tbk yang terdaftar di BEI mulai priode 2013 sampai dengan 2018. Penelitian ini menggunakan model prediksi kebangkrutan Zmijewski ( $X$ Score) dengan menghitung rasio-rasio yang bersumber dari laporan keuangan dan dirumuskan dengan fungsi persamaan sebagai berikut:

X-Score $=-,-, \quad+,-$,

$\mathrm{X}_{1}=\longrightarrow(R O A)$

$$
\mathrm{X}_{2}=\overline{(\text { Leverage Ratio })}
$$

$$
\mathrm{X}_{3}=\overline{\text { (Liquidity Ratio) }}
$$

Dimana jika hasil dari perhitungan Zmijewski tersebut nilai dari $\mathrm{X}<0$ perusahaan masuk dalam kategori sehat, dan jika nilai dari $\mathrm{X}>0$ maka perusahaan berpotensi bangkrut.

\section{HASIL DAN PEMBAHASAN}

Tabel 1

$$
\text { Hasil Perhitungan Nilai X-Score }
$$

PT Bentoel Internasional Investama Tbk

\begin{tabular}{|l|c|c|c|c|c|c|}
\hline \multicolumn{1}{|c|}{ Ket } & $\mathbf{2 0 1 3}$ & $\mathbf{2 0 1 4}$ & $\mathbf{2 0 1 5}$ & $\mathbf{2 0 1 6}$ & $\mathbf{2 0 1 7}$ & $\mathbf{2 0 1 8}$ \\
\hline Hasil X- & 1,282 & 3,007 & 3,390 & $-1,908$ & $-2,066$ & $-1,627$ \\
Score & & & & & \\
\hline Batas & $<0$ & $<0$ & $<0$ & $<0$ & $<0$ & $<0$ \\
Standar & & & & & & \\
\hline Posisi & PB & PB & PB & S & S & S \\
\hline
\end{tabular}

Sumber : $\quad$ diolah

$$
\begin{aligned}
& \mathrm{PB}=\text { Potensi Bangkrut } \\
& \mathrm{S}=\text { Sehat }
\end{aligned}
$$

Jika dilihat dari hasil $X$-Score pada PT Bentoel Internasional Investama Tbk selama tahun 2013-2018 dapat dikategorikan sebagai perusahaan yang mulai menunjukkan adanya perubahan yang positif. Hal ini dapat terlihat dalam tabel diatas. Pada tahun 2013, perusahaan memiliki nilai $X$-Score sebesar 1,282. Hasil ini menunjukkan bahwa PT 
Bentoel Internasional Investama Tbk berpotensi bangkrut, karena nilai batas bawah dari $X$-Score adalah jika nilai dari $X$-Score $>0$ perusahaan masuk kategori bangkrut dan jika nilai $X$-Score $<0$, maka perusahaan dalam kondisi sehat. Hal ini terjadi karena pada tahun ini adalah awal mula terjadinya peningkatan tarif cukai, dan beban operasional lainnya yang mengakibatkan laba yang diterima oleh perusahaan menjadi minus. Ditahun selanjutnya, yaitu pada tahun 2014, kondisi perusahaan semakin mengkhawatirkan, karna nilai dari $X$-Score sudah mencapai 3,007. Hal ini disebabkan karena terjadinya peningkatan hutang yang lebih tinggi daripada aset yang dimiliki perusahaan. Ditahun ini total hutang perusahaan mencapai Rp12,11 triliun, sementara total aset yang dimiliki perusahaan hanya Rp20,82 triliun. Nilai $X$-Score tertinggi yang diperoleh PT Bentoel jatuh pada tahun selanjutnya, yaitu pada 2015. Hasil nilai $X$ Score mencapai 3,390. Hasil ini merupakan hasil tertinggi selama periode 2013 sampai dengan 2018. Keadaan perusahaan semakin terpuruk, karena perusahaan masih belum mampu mengoptimalkan pendapatan yang diperolehnya agar dapat menutupi bebanbeban yang telah dikeluarkan. Ditambah lagi dengan terjadinya lagi peningkatan total hutang yang mencapai Rp15,82 triliun, sementara total aset yang dimiliki oleh perusahaan hanya sebesar RP12,66 triliun. Lebih tinggi Rp3,15 triliun hutang daripada aset yang dimiliki oleh perusahaan. Pada tahun selanjutnya ditahun 2016, terjadi peningkatan positif yang telah dilakukan oleh perusahaan. Nilai dari $X$-Score menunjukkan hasil -1,908 yang artinya keadaan perusahaan mulai masuk dalam kategori sehat. Hal ini terjadi karena, jumlah hutang yang dimiliki oleh perusahaan menurun drastis. Pada tahun ini hutang perusahaan turun sebesar Rp11,78 triliun dari tahun sebelumnya, menjadi Rp4,03 triliun. Pada tahun ini pun terjadi peningkatan aset di banding tahun sebelumnya. Perusahaan memiliki total aset sebesar Rp13,47 triliun, sehingga dapat terlihat dari grafik diatas bahwa mulai tahun 2016 ini, perusahan sudah termasuk kategori sehat. Pada tahun 2017, jika dilihat dari grafik diatas, nilai dari $X$-Score yang diperoleh perusahaan ditahun ini adalah 2,066. Ini menunjukkan peningkatan yang semakin positif, karena nilai $X$-Score semakin menjauhi batas nilai 0. Dapat dilihat pula, pada tahun ini kerugian yang diderita perusahaan adalah kerugian yang paling sedikit selama priode 2013-2018. Kerugian perusahaan adalah Rp480 milyar, dibandingkan dengan tahun-tahun sebelumnya yang mencapai triliunan rupiah. Pada tahun 2018, jika dilihat dari grafik diatas, perusahaan mengalami penurunan nilai $X$-Score menjadi -1,627. Ini menunjukkan bahwa pada tahun ini perusahaan mengalami penurunan kinerja. Terbukti dari meningkatnya kembali kerugian yang dialami perusahaan yang awalnya Rp480 milyar menjadi Rp608 milyar. Hal ini terjadi karena beban-beban yang ditanggung perusahaan semakin meningkat dibandingkan 
dari tahun sebelumnya. Begitu pula pada hutang perusahaan pun semakin meningkat. Pada tahun sebelumnya, hutang yang dimiliki perusahaan sebesar Rp5,16 triliun sementara di tahun 2018 ini, hutang perusahaan mencapai Rp 6,51 triliun. Meningkat sebesar $135 \%$ dibanding tahun sebelumnya. Namun, jika dibandingkan dari tahun 2013 sampai dengan 2016, kerugian pada tahun ini lebih sedikit dibandingkan 4 tahun tersebut yang mencapai hingga triliunan rupiah, serta pada komponen $\mathrm{X}_{1}, \mathrm{X}_{2}$, dan $\mathrm{X}_{3}$ pada tahun 2018 ini pun bukan merupakan kinerja paling buruk dalam rentang waktu penelitian tersebut dan perusahaan masih masuk dalam kategori sehat.

\section{PENUTUP}

\section{Simpulan}

Berdasarkan hasil pembahasan pada bab sebelumnya terhadap laporan keuangan PT Bentoel Internasional Investama Tbk pada tahun 2013 sampai dengan 2018 dengan menggunakan metode Zmijewski (X-Score), maka dapat dilihat bahwa pada tahun 2013 sampai dengan 2015 PT Bentoel berpotensi bangkrut, hal ini terjadi karena pada tahun 2013 sampai dengan 2015 jumlah kewajiban yang dimiliki oleh PT Bentoel lebih tinggi daripada jumlah aset yang dimiliki oleh perusahaan dan ditambah dengan kerugian yang diderita menyebabkan PT Bentoel berada dalam posisi berpotensi bangkrut. Sedangkan ditahun 2016 sampai dengan 2018 PT Bentoel berada dalam posisi sehat. Hal ini terjadi karena perlahan-lahan PT Bentoel mampu menurunkan jumlah kewajibannya sehingga nilai aset PT Bentoel lebih tinggi daripada kewajibannya, meskipun dalam rentang tahun 2016 sampai dengan 2018 PT Bentoel masih mengalami kerugian, namun kerugian yang diderita pada 2017 dan 2018 tidak sebesar pada tahun sebelumnya yang mencapai triliunan rupiah.

\section{Saran}

Saran yang bisa saya berikan untuk perusahaan yaitu perusahaan harus mampu Meminimalisirkan beban-beban yang dikeluarkan oleh perusahaan, sebab perusahaan sebenarnya mampu meningkatkan penjualan, namun tidak mampu menekan beban-beban yang dikeluarkan sehingga perusahaan masih mengalami kerugian. Beban-beban dapat ditekan dengan cara dalam memproduksi rokok, perusahaan harus memperhatikan kinerja penjualan pada tahun lalu, jangan sampai perusahaan memproduksi rokok terlalu banyak yang dapat mengakibatkan beban pokok penjualan meningkat. Perusahaan harus memproduksi dibawah dari beban pokok penjualan yang dikeluarkan pada tahun sebelumnya, jangan sampai perusahaan memproduksi barang terlalu banyak, yang melebihi dari hasil penjualan yang mampu diperolehnya.

\section{DAFTAR PUSTAKA}

Fachrudin. (2009). Kesulitan Keuangan 
Perusahaan Dan Personal. Medan: Usu

Pres.

Farid, \& Siswanto. (2013). Analisis Laporan

Keuangan. Bandung: PT Bumi Aksara.

Harahap, S. S. (2015). Analisis Kritis Atas

Laporan Keuangan (12th ed.). Jakarta:

PT Raja Grafindo Persada.

Harmono. (2011). Manajemen Keuangan.

Jakarta: PT Bumi Aksara.

Ikatan Akuntansi Indonesia. (2009). Standar

Akuntansi Indonesia. Jakarta.

Jumingan. (2010). Analisis Laporan

Moleong, L. J. (2017). Metodologi Penelitian

Kualitatif dan Kuantitatif. Bandung: PT

Remaja Rosdakarya.

Perintis.

Sugiyono. (2018). Metode Penelitian

Kuantitatif, Kualitatif, Dan $R \& D$.

Bandung: Alvabeta. 